\title{
Fungal microbiota from rain water and pathogenicity of Fusarium species isolated from atmospheric dust and rainfall dust
}

\author{
D. Palmero $\cdot$ J. M. Rodríguez $\cdot$ M. de Cara $\cdot$ \\ F. Camacho $\cdot$ C. Iglesias $\cdot$ J. C. Tello
}

\begin{abstract}
In order to determine the presence of Fusarium spp. in atmospheric dust and rainfall dust, samples were collected during September 2007, and July, August, and October 2008. The results reveal the prevalence of airborne Fusarium species coming from the atmosphere of the South East coast of Spain. Five different Fusarium species were isolated from the settling dust: Fusarium oxysporum, $F$. solani, F. equiseti, $F$. dimerum, and $F$. proliferatum. Moreover, rainwater samples were obtained during significant rainfall events in January and February 2009. Using the dilution-plate method, 12 fungal genera were identified from these rainwater samples. Specific analyses of the rainwater revealed the presence of three species of Fusarium: $F$. oxysporum, $F$. proliferatum and $F$. equiseti. A total of 57 isolates of Fusarium spp. obtained from both rainwater and atmospheric rainfall dust sampling were inoculated onto melon (Cucumis melo L.) cv. Piñonet and tomato (Lycopersicon esculentum Mill.) cv. San Pedro. These species were chosen because they are the main herbaceous crops in Almeria province. The results presented in this work indicate strongly that spores or propagules of Fusarium are able to cross the continental barrier carried by winds from the Sahara (Africa) to crop or coastal
\end{abstract}

lands in Europe. Results show differences in the pathogenicity of the isolates tested. Both hosts showed root rot when inoculated with different species of Fusarium, although fresh weight measurements did not bring any information about the pathogenicity. The findings presented above are strong indications that long-distance transmission of Fusarium propagules may occur. Diseases caused by species of Fusarium are common in these areas. They were in the past, and are still today, a problem for greenhouses crops in Almería, and many species have been listed as pathogens on agricultural crops in this region. Saharan air masses dominate the Mediterranean regions. The evidence of long distance dispersal of Fusarium spp. by atmospheric dust and rainwater together with their proved pathogenicity must be taken into account in epidemiological studies.

Keywords Airborne fungi Aeromycobiota $\cdot$ Fusarium

\section{Introduction}

Most studies conducted on atmospheric dust have considered it to originate mainly in the Sahara and Sahel regions of Africa [11, 12]. Some authors consider the Sahara as the main source of sediments transported by dust to far away areas such as Caribbean Islands [25, 26], Russia, Germany or Great Britain [6]. The importance of these deposits (2 million metric tons of dust each year) can even influence the geological evolution of many soils [12]. But there are many aspects that need further investigation. One of these concerns the microbiological aspects of such large movements of dust and the role of rainfall in its deposition. Particulate microorganisms in air have been broadly studied $[4,12]$. A statistical correlation between the presence of 
desert dust and observed increases in the number of colony forming units (cfu) has also been reported [10, 12, 13]. Infectivity and respiratory tract penetration in humans has also been studied for pathogenic organisms [9]. The genus Fusarium has regularly been isolated in these works but no specific studies have been performed and frequently only the genus is indicated without species assignation $[9,15$, 32]. Fusarium spp. propagules have been recovered from grain dust [8]. Evidence of long-distance transport in the atmosphere has been reported for Gibberella zeae (teleomorph of Fusarium graminearum and causal agent of Fusarium head blight of wheat and barley and Giberrella ear rot on maize). Atmospheric populations have been proposed as the origin of the inoculum causing epidemics of these diseases [8, 27]. Abdel-Hafez et al. [1] recovered 24 genera and 57 species of fungi from air dust samples in Egypt; $1.26 \%$ of the total were Fusarium spp. isolates. Some $F$. oxysporum and $F$. solani isolates were toxic to brine shrimp and some of them proved to be zearalenone producers. A total of 44 fungal genera and 102 species were recovered from airborne mycobiota from the Egyptian desert [16], of which only two species within the Fusarium genus were isolated $(F$. dimerum and $F$. oxysporum). Fusarium genus was recovered as only $0.3 \%$ of the overall sample.

Dispersal in aquatic systems has also been previously proved for Fusarium culmorum [29], and spread of Fusarium spp. via irrigation water has been described for some species causing plant diseases in greenhouses [7]. Wind and rain dispersal of Fusarium moniliforme have also been studied in corn fields [22]. But research focussing on the occurrence of this genus in aquatic habitats is not common, perhaps because Fusarium spp. are generally considered to be soil-borne fungi. Tello and Lacasa [30] and Palmero et al. [23] studied the presence of species of Fusarium in uncultivated land, finding a high proportion of $F$. solani and $F$. oxysporum; however, the authors questioned the ability of the isolates (especially $F$. oxysporum) to cause diseases in plants cultivated close by.

The transport of atmospheric dust is a phenomenon with global character. From the microbiological point of view, its effects have been studied for certain genera, including several foliar pathogens such as rusts, powdery mildew, etc., but rarely for soil-borne pathogens [5]. This study attempts (1) to determine possible new sources of inoculum of Fusarium species by studying both rainwater and atmospheric settling dust collected in Almeria, Spain, and (2) to determine their pathogenicity by studying the effect of the recovered Fusarium strains on damping off in seedlings of the two main species cultivated in the area: tomato and melon.

\section{Materials and methods}

Almeria province is located on the Spanish Mediterranean coast at a mid-altitude position that is influenced by highlatitude and subtropical wind systems. It is an arid region characterised by intensive agriculture in plastic greenhouses.

\section{Dust sampling}

In order to determine whether Fusarium spp. are present in atmospheric dust and rainfall dust (downfall dust), samples were collected during September 2007, and July, August, and October 2008 in disinfected trays $\left(0.192\right.$ and $\left.0.322 \mathrm{~m}^{2}\right)$ (Table 1). Analysis of dust samples consisted of adding $0.02 \mathrm{~g}$ atmospheric dust to a Fusarium selective medium as described by Komada [17] and modified by Tello et al. [31]. Twenty Petri dishes per sample were used, and divided into four blocks of five dishes. Plates were incubated for 10 days at laboratory temperature under continuous fluorescent light. The mean number of cfu per Petri dish, and the standard deviation of the mean was calculated for all Fusarium colonies, and used as the basis for comparisons. Downfall dust samples collected during rainfall events were analysed following the same methodology as indicated for atmospheric dust but samples were previously dried under aseptic conditions at room temperature $\left(20-25^{\circ} \mathrm{C}\right)$.

\section{Rain water sampling}

Water samples were obtained during significant rainfall events in January and February 2009 (Table 1). All water samples were collected in plastic trays $\left(0.322 \mathrm{~m}^{2}\right)$ and rain water transferred to a $200 \mathrm{ml}$ sterile plastic jars (Eurotubo Deltalab: Plaza de la Verneda, 1, 08191 Rubí, Barcelona). Samples were analysed within 24 to $48 \mathrm{~h}$ after collecting them. Sampling dates are listed in Table 1.

Analysis of the fungal microbiota in water samples involved gently shaking each jar, transferring $1 \mathrm{ml}$ of the rain water sample to a $9 \mathrm{~cm}$ Petri dish containing $10 \mathrm{ml}$ non-selective medium (Malta agar), cooled to $35^{\circ} \mathrm{C}$, then gently agitating the mixture to assure fusion of the sample water and agar. A total of 20 dishes per sample were set up in this way, and divided randomly into four blocks of 5 dishes. Plates were incubated for 10 days at laboratory temperature $\left(25^{\circ} \mathrm{C}\right)$ under continuous fluorescent light. The mean cfu per Petri dish and the standard deviation of the mean were calculated for all colonies, and used as the basis for comparisons. Using this same methodology, specific analysis with a selective medium for Fusarium genus were conducted with the rainwater samples [17]. 
Table 1 Characteristics of rainfall dust and rain water samples collected in Almería (Spain) from 2007 to 2009

\begin{tabular}{|c|c|c|c|c|}
\hline Sample code & Sampling date & Sample type & Exposed area & Rainfall (date and quantity) \\
\hline Lluv1 & 11 September 2007 & Rainfall dust & $0.1924 \mathrm{~m}^{2}$ & $\begin{array}{l}10 \text { September } 2007 \rightarrow 0.51 \mathrm{ml} \\
11 \text { September } 2007 \rightarrow 1.02 \mathrm{ml}\end{array}$ \\
\hline Ven 1 & $\begin{array}{l}17 \text { July } 2008 \\
30 \text { August } 2008\end{array}$ & Atmospheric dust & $0.1924 \mathrm{~m}^{2}$ & No rain was recorded \\
\hline Ven 2 & 1 October 2008 & Rainfall dust & $0.322 \mathrm{~m}^{2}$ & 9 October $2008 \rightarrow 3.3 \mathrm{~mm}$ \\
\hline AG.Fu & 30 October 2008 & Rainfall dust & $0.322 \mathrm{~m}^{2}$ & $\begin{array}{l}10 \text { October } 2008 \rightarrow 12.7 \mathrm{~mm} \\
11 \text { October } 2008 \rightarrow 0.25 \mathrm{~mm}\end{array}$ \\
\hline Lluv 2 & $\begin{array}{l}5 \text { January } 2009 \\
9 \text { January } 2009\end{array}$ & Rain water & $0.322 \mathrm{~m}^{2}$ & $\begin{array}{l}5 \text { January } 2009 \rightarrow 8.89 \mathrm{~mm} \\
7 \text { January } 2009 \rightarrow 0.25 \mathrm{~mm} \\
8 \text { January } 2009 \rightarrow 1.27 \mathrm{~mm} \\
9 \text { January } 2009 \rightarrow 6.10 \mathrm{~mm}\end{array}$ \\
\hline Lluv 3 & 6 February 2009 & Rain water & $0.322 \mathrm{~m}^{2}$ & $\begin{array}{l}1 \text { February } 2009 \rightarrow 0 \mathrm{~mm} \\
2 \text { February } 2009 \rightarrow 7.87 \mathrm{~mm} \\
3 \text { February } 2009 \rightarrow 2.29 \mathrm{~mm} \\
4 \text { February } 2009 \rightarrow 1.27 \mathrm{~mm} \\
5 \text { February } 2009 \rightarrow 2.54 \mathrm{~mm} \\
6 \text { February } 2009 \rightarrow 4.06 \mathrm{~mm}\end{array}$ \\
\hline
\end{tabular}

Table 2 Fusarium species isolated from settling atmospheric dust and rainwater samples

\begin{tabular}{lllclll}
\hline Sample code & \multicolumn{7}{l}{ Fusarium species recovered $^{\mathrm{c}}$} \\
\cline { 2 - 7 } & F.oxy & F.sol & F.eq & F. pro & F. dim & Acre \\
\hline Lluv $^{\mathrm{a}}$ & $41.31 \pm 33.59$ & $86.38 \pm 43.23$ & $2,054.46 \pm 616.66$ & $15.02 \pm 24.48$ & 0 & 0 \\
Ven 1 $^{\mathrm{a}}$ & $32.49 \pm 27.38$ & $57.71 \pm 24.91$ & $181.05 \pm 132.71$ & $4.64 \pm 11.37$ & $27.85 \pm 35.23$ & 0 \\
Ven 2 $^{\text {a }}$ & $45.59 \pm 60.02$ & $55.72 \pm 44.74$ & $303.95 \pm 54.37$ & $10.13 \pm 15.69$ & $15.19 \pm 25.43$ & 0 \\
AG.Fu $^{\text {a }}$ & $24.87 \pm 49.75$ & $1,305.97 \pm 522.38$ & $1,990.04 \pm 495.85$ & $2.599 .50 \pm 907.76$ & $87.06 \pm 47.63$ & $746.26 \pm 211.07$ \\
Lluv 2 $^{\text {b }}$ & $0.15 \pm 0.36$ & 0 & $2.55 \pm 2.45$ & 0 & 0 & $2.35 \pm 2.75$ \\
Lluv 3 $^{\text {b }}$ & $0.13 \pm 0.34$ & 0 & $0.23 \pm 0.50$ & $0.93 \pm 1.17$ & 0 & 0 \\
\hline
\end{tabular}

${ }^{\text {a }}$ Presence of species of Fusarium expressed in number of colonies per gram (cfu g ${ }^{-1}$ dry dust) followed by the average standard deviation

${ }^{b}$ Presence of species of Fusarium expressed in number of colonies per millilitre (cfu ml ${ }^{-1}$ water) followed by the average standard deviation

${ }^{\circ}$ F. oxy Fusarium oxysporum, F.sol F. solani, F.pro F. proliferatum, F.dim F. dimerum, F.eq F. equiseti, Acre Acremonium

Maintenance and identification of fungal colonies

The entire collection of Fusarium isolates was maintained on potato dextrose agar (PDA) and Komada's media and stored at $4^{\circ} \mathrm{C}$ in the fungus collection of the Plant Production Department of the University of Almeria and in the Technical University of Madrid. The identification procedures and the taxonomic criteria of Barnet and Hunter [2] within the division of Deuteromycetes, and those of Nelson et al. [21] and Leslie and Summerell [18] within the Fusarium genus were followed to assign isolates to species level.

\section{Pathogenicity tests}

A total of 57 isolates of Fusarium obtained during both rainwater and atmospheric rainfall dust sampling were inoculated onto melon (Cucumis melo L.) cv. Piñonet and tomato (Lycopersicon esculentum Mill.) cv. San Pedro.

Inoculation tests were conducted following a modification of the technique proposed by Messiaen et al. [19] used previously for pathogenicity testing of Fusarium isolates from fluvial water [24]. Inoculum for each isolate was prepared by growing the culture for 2 weeks in complete darkness on PDA plates kept at $25^{\circ} \mathrm{C}$ until the colony reached the edge of the dish. Plastic $350 \mathrm{ml}$ greenhouse pots were filled to two-thirds capacity with disinfected $\left(30 \mathrm{~min}\right.$ at $120^{\circ} \mathrm{C}$ ) vermiculite substrate [Agroalse, Moncada, Valencia, Spain]. A fungal colony was then scraped off a PDA plate and added to the surface of a pot. Three pots were used per Fusarium isolate. Seeds were first disinfected with sodium hypochlorite (active chlorine 4-5\%) for $15 \mathrm{~min}$, then washed with sterile water. Thereafter, ten germinating seeds (with a root length of $1-2 \mathrm{~cm}$ at the time 
Table 3 Fungal aeromicrobiota isolated from rainwater in Almería (Spain) expressed in colony forming units per millilitre (cfu $\mathrm{ml}^{-1}$ ) water followed by the average standard deviation

\begin{tabular}{lrr}
\hline $\begin{array}{l}\text { Morphological ID } \\
\text { for Fungi }\end{array}$ & \multicolumn{1}{c}{$\begin{array}{l}\text { January 2009 } \\
\text { cfu ml }\end{array}$} & \multicolumn{1}{c}{$\begin{array}{c}\text { February 2009 } \\
\text { cfu ml }^{-1}\end{array}$} \\
\hline Acremonium sp. & $6.9 \pm 7.56$ & $0.06 \pm 0.36$ \\
Aspergillius spp. & $0.1 \pm 0.30$ & $0.03 \pm 0.18$ \\
Alternaria sp. & $1.8 \pm 1.64$ & $0.03 \pm 0.18$ \\
Aureobasidium sp. & $0.15 \pm 0.36$ & $8.5 \pm 8.45$ \\
Beauveria bassiana & $0.9 \pm 1.68$ & $0 \pm 0.00$ \\
Botrytis cinerea & $0.4 \pm 0.59$ & $0.06 \pm 0.25$ \\
Cladosporium sp. & $11.45 \pm 3.77$ & $0.76 \pm 1.04$ \\
Epicoccum sp. & $0.1 \pm 0.30$ & $0 \pm 0.00$ \\
Fusarium sp. & $0.4 \pm 0.75$ & $0 \pm 0.00$ \\
F. axysporum & $0.15 \pm 0.67$ & $0.16 \pm 0.37$ \\
F. proliferatum & $0.9 \pm 1.61$ & $0.96 \pm 1.54$ \\
F. equiseti & $0.5 \pm 0.68$ & $0 \pm 0.00$ \\
Penicillium spp. & $0.7 \pm 0.97$ & $0.13 \pm 0.34$ \\
Phoma sp. & $0.3 \pm 0.47$ & $0.1 \pm 0.40$ \\
Rhizopus sp. & $0.15 \pm 0.36$ & $0 \pm 0.00$ \\
Sthemphyllium sp. & $0 \pm 0.00$ & $0.03 \pm 0.18$ \\
Unidentified & $0.15 \pm 0.67$ & $0.4 \pm 0.56$ \\
\hline
\end{tabular}

of sowing, which takes 6 days for melon and 5 days for tomato) were placed in each pot, and covered with $1 \mathrm{~cm}$ layer of disinfected vermiculite. Once the pot was full, it was watered to saturation, and then with $250 \mathrm{ml}$ water every 2 days. Care was taken to prevent pot leachates from contaminating other pots by keeping inoculated pots with different isolates in different trays and removing excess water from the trays daily. A sterile agar control was included in the inoculation test for each species of Fusarium tested. Inoculated and control plants were kept in a growth chamber set at $24-27^{\circ} \mathrm{C}$ under a photoperiod of $16 \mathrm{~h}$ at $12,000 \mathrm{~lx}$.

Plants in plots were rated every 5 days for percent emergence. After 20 days, plants were evaluated for the percentage of damping off [28] and non-emerged germinating seeds were uncovering and symptoms observed. $\mathrm{Re}$ isolation and identification of Fusarium species was done on PDA medium for all plants and isolates. The experiment was repeated.

\section{Results and discussion}

The results show the prevalence of airborne Fusarium species coming from the atmosphere in the South East coast of Spain (Table 2). Five different Fusarium species were isolated from settling dust: Fusarium oxysporum, $F$. solani, $F$. equiseti, $F$. dimerum, and $F$. proliferatum. Previous studies have shown that Basidiomycetes and Ascomycetes can be transported passively by wind, and that the ambient concentration and number of spores of
Table 4 Incidence of damping off on locally grown plant species inoculated with isolates of Fusarium recovered from atmospheric dust of Almería (south-eastern Spain)

Values with the same lower case letter did not differ significantly

${ }^{\mathrm{f}}$ Inoculation studies were repeated

g Percent germination

(value $\pm \mathrm{SD}$ )

${ }^{\mathrm{h}}$ Non inoculated

\begin{tabular}{llcc}
\hline Code of isolate & Fusarium species & Tomato $^{\mathrm{f}}$ & Melon $^{\mathrm{f}}$ \\
\hline FV1 & F. solani & $53.33^{\mathrm{g}} \pm 23.15 \mathrm{bcd}$ & $98.33 \pm 22.72 \mathrm{de}$ \\
FV2 & F. solani & $36.67 \pm 23.09 \mathrm{abcd}$ & $100 \pm 23.12 \mathrm{e}$ \\
FV3 & F. solani & $46.67 \pm 23.4 \mathrm{bcd}$ & $88.33 \pm 23.5 \mathrm{bcde}$ \\
FV4 & F. solani & $56.67 \pm 23.86 \mathrm{bcd}$ & $91.67 \pm 23.58 \mathrm{bcde}$ \\
FV13 & F. proliferatum & $65 \pm 23.63 \mathrm{~d}$ & $96.67 \pm 24.08 \mathrm{de}$ \\
FV14 & F. dimerum & $53.33 \pm 23.53 \mathrm{bcd}$ & $100 \pm 24.62 \mathrm{e}$ \\
FV15 & F. dimerum & $46.67 \pm 23.76 \mathrm{bcd}$ & $95 \pm 25.09 \mathrm{cde}$ \\
FV20 & F. oxysporum & $36.67 \pm 23.95 \mathrm{abcd}$ & $91.67 \pm 25.7 \mathrm{bcde}$ \\
FV21 & F. oxysporum & $38.33 \pm 24.08 \mathrm{abcd}$ & $88.33 \pm 26.38 \mathrm{bcde}$ \\
FV22 & F. oxysporum & $40 \pm 24.38 \mathrm{abcd}$ & $98.33 \pm 27.17 \mathrm{de}$ \\
FV23 & F. oxysporum & $33.33 \pm 24.96 \mathrm{ab}$ & $90 \pm 27.85 \mathrm{bcde}$ \\
FV27 & F. equiseti & $41.67 \pm 24.59 \mathrm{ab}$ & $65 \pm 28.68 \mathrm{~b}$ \\
FV28 & F. equiseti & $40 \pm 22.42 \mathrm{abcd}$ & $83.33 \pm 27.85 \mathrm{bcde}$ \\
FV29 & F. equiseti & $35 \pm 22.44 \mathrm{abc}$ & $90 \pm 29.05 \mathrm{bcde}$ \\
FV30 & F. equiseti & $61.67 \pm 23.02 \mathrm{bcd}$ & $78.33 \pm 30.33 \mathrm{bcd}$ \\
FV31 & F. equiseti & $48.33 \pm 23.03 \mathrm{bcd}$ & $93.33 \pm 29.32 \mathrm{bcde}$ \\
FV32 & F. equiseti & $53.33 \pm 22.74 \mathrm{bcd}$ & $93.33 \pm 31.16 \mathrm{bcde}$ \\
FV33 & F. equiseti & $51.67 \pm 22.11 \mathrm{bcd}$ & $100 \pm 33.37 \mathrm{e}$ \\
FV38 & F. proliferatum & $33.33 \pm 23.15 \mathrm{ab}$ & $76.67 \pm 33.59 \mathrm{bc}$ \\
FV39 & F. proliferatum & $18.33 \pm 26.91 \mathrm{a}$ & $35 \pm 37.53 \mathrm{a}$ \\
Control & & $63.33 \pm 17.95 \mathrm{~cd}$ & $75 \pm 25 \mathrm{bcd}$ \\
\hline & &
\end{tabular}


fungi such as Penicillium, Aspergillus and Nigrospora increase significantly during sandstorm episodes. This is a possible explanation for the observed increase in Fusarium colonies in sample "AG.Fu", when a sandstorm episode took place. However, Fusarium species appeared regularly in analysed samples of settling dust so this cannot be the only explanation. These results are in agreement with those reported by Ismail et al. [16] for airborne mycobiota in the desert of Egypt for $F$. dimerum and F. oxysporum, and with the observations of Abdel-Hafez et al. [1], who recovered $F$. oxysporum and $F$. solani from Upper Egypt.

The results also agree with those of Tello and Lacasa [30], who reported the capacity of winds to carry dust particles and disseminate Fusarium spp. propagules. On a $8.75 \mathrm{~m}^{2}$ surface exposed to wind south of the Canary Islands, they recovered $12,598 \mathrm{cfu}$ of $F$. solani and 8,712 cfu of $F$. verticillioides. F. equiseti was collected from dust particles from the Saharan winds on the European coast. These studies demonstrate the ability of Fusarium spp. to be spread by the wind. The results presented in this work strongly indicate that spores or propagules of Fusarium spp. are able to cross the continental barrier carried by winds from the Sahara (Africa) to crop and coastal lands in Europe.

We cannot specifically discuss rainfall dust in samples obtained in 2007 and 2008 because it took several weeks and it was not raining all the time so settling atmospheric dust was also collected. For this reason we directly analysed rain water collected in 2009 .

Using the dilution-plate method, 12 fungal genera were identified from rainwater samples collected during January and February 2009 in Almería (Spain). From our results, Cladosporium, Acremonium and Aureobasidium are the most predominant fungal spores, comprising more than $73 \%$ of total fungal spores per millilitre (Table 3). Cladosporium is one of the most dominant fungi recovered in outdoor atmospheric environments [12]. The rainwater analysis revealed a large content of airborne fungal spores (9,084 cfu of Botrytis cinerea were recovered per square metre). Some of these fungi are considered plant pathogens, for example Acremonium, B. cinerea and some species of Fusarium and Alternaria. Others, such as Aspergillus, Alternaria, Cladosporium, Fusarium, Penicillium and Rhizopus, have been cited as the cause of postharvest losses. Others still have been used as biological agents to control pests in greenhouses (Beauveria bassiana). The number of fungal propagules per millilitre was seemingly small (Table 3), but if we consider that the total amount of rainfall in the sampling date was $22.74 \mathrm{~L}$ $\mathrm{m}^{-2}$, a simple multiplication shows us that 9,084 cfu of Botrytis cinerea - an important pathogen in the studied area for tomatoes, peppers, zucchini, or eggplants—settled in $1 \mathrm{~m}^{2}$.
Table 5 Incidence of damping off on locally grown plant species inoculated with isolates of Fusarium recovered from atmospheric downfall dust of Almería (south-eastern Spain)

\begin{tabular}{|c|c|c|c|}
\hline $\begin{array}{l}\text { Code of } \\
\text { isolate }\end{array}$ & $\begin{array}{l}\text { Fusarium } \\
\text { species }\end{array}$ & Tomato $^{\mathrm{d}}$ & Melon $^{\mathrm{d}}$ \\
\hline F1 & F. solani & $51.67^{\mathrm{e}} \pm 30.47 \mathrm{bc}$ & $98.33 \pm 8.39 b$ \\
\hline $\mathrm{F} 2$ & F. proliferatum & $41.67 \pm 30.29 \mathrm{abc}$ & $93.33 \pm 8.57 b$ \\
\hline F12 & F. solani & $35 \pm 30.28 \mathrm{abc}$ & $93.33 \pm 8.6 b$ \\
\hline F13 & F. solani & $50 \pm 30.66 \mathrm{bc}$ & $100 \pm 8.62 \mathrm{~b}$ \\
\hline F14 & F. solani & $6.67 \pm 30.68 \mathrm{a}$ & $100 \pm 8.89 b$ \\
\hline F18 & F. equiseti & $38.33 \pm 30.36 \mathrm{abc}$ & $100 \pm 9.17 b$ \\
\hline F36 & F. equiseti & $38.33 \pm 30.81 \mathrm{abc}$ & $100 \pm 9.49 b$ \\
\hline F43 & F. solani & $58.33 \pm 30.55 \mathrm{c}$ & $93.33 \pm 9.84 b$ \\
\hline F44 & F. oxysporum & $45 \pm 30.69 \mathrm{bc}$ & $98.33 \pm 10.02 b$ \\
\hline F45 & F. solani & $50 \pm 31.56 \mathrm{c}$ & $100 \pm 10.46 b$ \\
\hline F46 & F. proliferatum & $11.67 \pm 31.38 \mathrm{ab}$ & $75 \pm 10.98 \mathrm{a}$ \\
\hline F55 & F. equiseti & $48.33 \pm 31.51 b c$ & $98.33 \pm 4.32 b$ \\
\hline F66 & F. oxysporum & $33.33 \pm 32.56 \mathrm{abc}$ & $98.33 \pm 4.41 \mathrm{~b}$ \\
\hline F67 & F. oxysporum & $33.33 \pm 32.35 \mathrm{abc}$ & $96.67 \pm 4.53 b$ \\
\hline F68 & F. oxysporum & $36.67 \pm 33.54 \mathrm{abc}$ & $98.33 \pm 3.31 b$ \\
\hline F88 & F. solani & $45 \pm 31.89 \mathrm{bc}$ & $96.67 \pm 3.14 b$ \\
\hline F89 & F. solani & $40 \pm 31.74 \mathrm{abc}$ & $100 \pm 0 \mathrm{~b}$ \\
\hline Control $^{\mathrm{f}}$ & & $58.33 \pm 31.84 \mathrm{c}$ & $100 \pm 0 \mathrm{~b}$ \\
\hline
\end{tabular}

Values with the same lower case letter did not differ significantly

${ }^{d}$ Inoculation studies were repeated

e Percentage germination (value $\pm \mathrm{SD}$ )

${ }^{\mathrm{f}}$ Non inoculated

Specific analyses of rainwater to detect the genus Fusarium revealed the presence of three species of Fusarium (Table 2): F. oxysporum, F. proliferatum and $F$. equiseti.

The presence of species of Fusarium in river water and the seabed of southeastern Spain was previously reported [23, 24], and fluvial sediment transport was suggested as the main route for the transportation of lithogenic and fungal particles to the Alboran Sea. The results presented here clearly suggest that those species could also be deposited in the sea by dust carried by wind or directly by rain.

Fusarium spp. are considered as important soil-borne plan pathogens that cause negative economic impacts on crop yield. Previous studies on aeromicrobiology did not address the issue of whether or not the Fusarium species isolated from this habitat were pathogenic to crops in the sampled areas. Therefore, it seemed necessary to evaluate the pathogenicity of the recovered isolates.

Pathogenicity assays were conducted with a total of 57 of the collected isolates of Fusarium species. A total of 20 isolates from the collected downfall dust (Table 4): 7 isolates of $F$. equiseti, 5 of $F$. oxysporum, 4 of $F$. solani, 2 of 
Table 6 Incidence of damping off on locally grown plant species inoculated with isolates of Fusarium recovered from rainwater in Almería (southeastern Spain)

\begin{tabular}{lllr}
\hline Code of isolate & Fusarium species & Tomato $^{\mathrm{g}}$ & Melon $^{\mathrm{g}}$ \\
\hline Fml1 & F. proliferatum & $73.33^{\mathrm{h}} \pm 20.82 \mathrm{def}$ & $86.67 \pm 19.80 \mathrm{~cd}$ \\
Fml2 & F. proliferatum & $36.67 \pm 20.56 \mathrm{abc}$ & $93.33 \pm 19.84 \mathrm{~cd}$ \\
Fml3 & F. proliferatum & $33.33 \pm 20.26 \mathrm{ab}$ & $96.67 \pm 20.21 \mathrm{~cd}$ \\
Fml4 & F. proliferatum & $53.33 \pm 19.56 \mathrm{abcdef}$ & $86.67 \pm 20.55 \mathrm{bc}$ \\
Fml5 & F. proliferatum & $43.33 \pm 19.64 \mathrm{abcd}$ & $83.33 \pm 21.00 \mathrm{bc}$ \\
Fml6 & F. proliferatum & $50.00 \pm 19.78 \mathrm{abcdef}$ & $86.67 \pm 21.40 \mathrm{bcd}$ \\
Fml7 & F. proliferatum & $73.33 \pm 19.82 \mathrm{cdef}$ & $93.33 \pm 21.77 \mathrm{~cd}$ \\
Fml8 & F. proliferatum & $60.00 \pm 19.99 \mathrm{abcdef}$ & $100.00 \pm 22.29 \mathrm{~d}$ \\
Fml9 & F. proliferatum & $66.67 \pm 20.47 \mathrm{bcdef}$ & $96.67 \pm 22.72 \mathrm{~cd}$ \\
Fml10 & F. proliferatum & $60.00 \pm 20.98 \mathrm{abcdef}$ & $83.33 \pm 23.25 \mathrm{bc}$ \\
Fml11 & F. proliferatum & $50.00 \pm 20.93 \mathrm{abcdef}$ & $86.67 \pm 23.88 \mathrm{bcd}$ \\
Fel1 & F. equiseti & $43.33 \pm 21.09 \mathrm{abcd}$ & $100.00 \pm 24.59 \mathrm{~d}$ \\
Fel2 & F. equiseti & $53.33 \pm 21.36 \mathrm{abcdef}$ & $100.00 \pm 25.20 \mathrm{~d}$ \\
Fel3 & F. equiseti & $53.33 \pm 21.83 \mathrm{abcdef}$ & $96.67 \pm 25.85 \mathrm{~cd}$ \\
Fel4 & F. equiseti & $73.33 \pm 21.24 \mathrm{cdef}$ & $100.00 \pm 26.66 \mathrm{~d}$ \\
Fel5 & F. equiseti & $60.00 \pm 21.59 \mathrm{abcdef}$ & $100.00 \pm 27.37 \mathrm{~d}$ \\
Fel6 & F. equiseti & $76.67 \pm 20.53 \mathrm{ef}$ & $100.00 \pm 28.07 \mathrm{~d}$ \\
Fol1 & F. oxysporum & $50.00 \pm 20.06 \mathrm{abcdef}$ & $100.00 \pm 28.70 \mathrm{~d}$ \\
Fol2 & F. oxysporum & $46.67 \pm 20.47 \mathrm{abcde}$ & $90.00 \pm 29.14 \mathrm{~cd}$ \\
Fol3 & F. oxysporum & $76.67 \pm 20.70 \mathrm{def}$ & $26.67 \pm 30.00 \mathrm{a}$ \\
Fol4 & F. oxysporum & $53.33 \pm 20.81 \mathrm{abcdef}$ & $36.67 \pm 24.46 \mathrm{a}$ \\
Fol5 & F. oxysporum & $26.67 \pm 22.90 \mathrm{a}$ & $70.00 \pm 13.82 \mathrm{~b}$ \\
Control & & $70.00 \pm 8.16 \mathrm{bcdef}$ & $100.00 \pm 0.00 \mathrm{~d}$ \\
\hline & & & \\
\hline & & & \\
\hline & & &
\end{tabular}

$F$. proliferatum, and 2 isolates of $F$. dimerum. And 17 isolates from the dust carried with rain water (after evaporation) (Table 5): 8 isolates of $F$. solani, 4 of $F$. oxysporum, 3 of $F$. equiseti, and 2 isolates of $F$. proliferatum were tested on tomato (Lycopersicum esculentum Mill), and melon (Cucumis melo L.), to evaluate their pathogenicity.

The results show differences in the pathogenicity of the isolates tested. Little pathogenicity was observed on tomato caused by $F$. oxysporum, $F$. proliferatum and $F$. equiseti, but none of the isolates of $F$. solani and $F$. dimerum were pathogenic on tomato (Table 4). On Cucumis melo L., two isolates of $F$. proliferatum caused significant decrease in seedling emergence. Regarding isolates from rainwater (Table 6), pathogenicity assays were conducted with 22 of the collected isolates: 11 isolates of $F$. proliferatum, 6 isolates of $F$. equiseti and 5 isolates of $F$. oxysporum. Pre and post-emergence pathogenicity was evaluated. This study of pathogenicity showed that some of these isolates caused pre-emergence damping-off on tomato seedlings. In the case of melon, most isolates of $F$. oxysporum (three out of five) caused important damping-off in seedlings. However, $F$. proliferatum and $F$. equiseti did not show pathogenicity on melon.

It could be concluded that a low number of recovered isolates show pathogenicity, but we must bear in mind that, in many cases, the introduction of new fungal pathogens has been evidenced to be airborne rather than carried by people or plants or plant products [5]. Most of these involved rust (with strong spores against environmental damage). The results presented here indicate that the same airborne dissemination pattern may occur for soil-borne fungi that have a markedly host specificity. This means that a single spore of a new race of a formae specialis of $F$. oxysporum can be transported over very long distances, and determine the original cause of a single-step pathogen invasion to new production areas far away from the pathogen origin.

\section{Conclusions}

The findings presented above are strong indicators that long-distance transmission of Fusarium can occur. Our results are coincident with those of Schmale et al. [27], who stated that inoculum can originate from multiple locations and, in practice, the existence of long-distance transport suggests that management of inoculum sources on a local scale will not be completely effective in managing fungal diseases.

The Mediterranean Sea acts as a reservoir in which evaporation exceeds freshwater input through precipitation and runoff [3]. Previous studies revealed the presence of five different Fusarium species in the river and sea water of 
southeastern Spain [23]. Fluvial sediments transport was proposed as the primary route for the transportation of lithogenic and fungal particulates to the Alboran Sea [20, 24]. The results presented here allow us to speculate on a new source of inoculum for Fusarium genus: atmospheric dust, which can fall down directly or together with rain.

On the other hand, diseases produced by species of Fusarium are common in these areas. They were in the past, and are still today, a problem for greenhouses crops in Almería, and many species have been listed as pathogens on agricultural crops in this region. Saharan air masses dominate the Mediterranean regions. Dust deposition over the western Mediterranean has been estimated at 9-25 tons $\mathrm{km}^{-2}$ year $^{-1}$ [14]. The evidence for long-distance dispersal of Fusarium spp. by atmospheric dust and rainwater, together with their proved pathogenicity, must be taken into account in epidemiological studies. Rainwater not only spreads the inocula of this soil-borne pathogen to new areas on a scale of hundreds of kilometres but also provides the necessary humidity for germination of the fungal spores.

This work reveals some epidemiological aspects of plant pathogenic fungi in natural environments. The presence of pathogenic species within the Fusarium genus in rainwater could indicate long distance dispersal in natural environments.

The evidence of long distance aerial dispersal of pathogenic strains of Fusarium species also has to be taken into account as a survival strategy within the population dynamics of plant pathogens as well as for plant protection strategies. Fusarium spores dispersed by wind from infected crops to new cultivated areas may overcome effective resistance. On the other hand, some of the isolated Fusarium spp. are potential mycotoxin producers. The ecotoxicological significance of their presence within rainwater remains to be elucidated.

\section{References}

1. Abdel-Hafez SII, Shoreit AAM, Abdel-Hafez AII, Maghraby MOE (1986) Mycoflora and mycotoxin-producing fungi of air dust particles from Egypt. Mycopathologia 93:25-32

2. Barnett HL, Hunter BB (1999) Illustrated genera of Imperfect fungi, 2nd printing, 4th edn. APS Press, The American Phytopathology Society, St. Paul, p 218

3. Béthoux JP (1979) Budgets of the Mediterranean Sea. Their dependance on the local climate and on the characteristics of the Atlantic waters. Oceanol Acta 2:157-163

4. Bovallius A, Bucht B, Roffey R, Anas P (1978) Long-range air transmission of bacteria. Appl Environ Microbiol 35:1231-1232

5. Brown JKM, Hovmoller MS (2002) Aerial dispersal of pathogens on the global and continental scales and its impact on plant disease. Science 297(5581):537-541

6. Díaz JL, Miranda JM (1997) Tasas de deposición de polvo atmosférico en un área semiárida del entorno Mediterráneo occidental. Estudios Geologicos 53:211-220
7. Elmer WH (2008) Preventing spread of Fusarium wilt of Hiemalis begonias in the greenhouse. Crop Prot 27:1078-1083

8. Fernando WGD, Miller JD, Seaman WL, Seifert K, Paulitz TC (2000) Daily and seasonal dynamics of airborne spores of Fusarium graminearum and other Fusarium species sampled over wheat plots. Can J Bot 78:497-505

9. Griffin DW (2007) Atmospheric movement of microorganism in clouds of desert dust and implications for human health. Clin Microbiol Rev 20(3):459-477

10. Griffin DW, Kellogg CA, Garrison VH, Lisle JT, Borden TC, Shinn EA (2003) African dust in the Caribbean atmosphere. Aerobiologia 19:143-157

11. Griffin DW, Kellogg CA, Garrison VH, Shinn EA (2002) The global transport of dust. Am Sci 90:228-235

12. Griffin DW, Kubilay N, Koçak M, Gray MA, Border TC, Shinn EA (2007) Airborne desert dust and aeromicrobiology over the Turkish Mediterranean coastline. Atmos Environ 41:4050-4062

13. Griffin DW, Westphal DL, Gray MA (2006) Airborne microorganism in the African desert dust corridor over the mid Atlantic ridge, ocean drilling program, leg 209. Aerobiologia 22:211-226

14. Guerzoni S, Molinaroli E, Chester R (1997) Saharan dust inputs to the western Mediterranean Sea: depositional patterns, geochemistry and sedimentological implications. Deep Sea Res PT II 44:631-654

15. Ho HM, Rao CY, Hsu HH, Chiu YH, Liu CM, Chao HJ (2005) Characteristics and determinants of ambient fungal spores in Hualien, Taiwan. Atmos Environ 39:5839-5850

16. Ismail MA, Abdel-Hafez SII, Moharram AM (2002) Aeromycobiota of western desert of Egypt. Afr J Sci Technol 3:1-9

17. Komada H (1975) Development of a selective medium for quantitative isolation of Fusarium oxysporum from natural soil. Rev Plant Prot Res 8:114-125

18. Leslie JF, Summerell BA (2006) The Fusarium laboratory manual. Blackwell, Ames

19. Messiaen CM, Belliard-Alonzol L, Barriere Y, De La Tullaye B (1976) Étude qualitative des Fusarium roseum dans les sols des environs de Versailles, sous diverses rotations ou associations végétales. Annu Rev Phytopathol 8:269-282

20. Moreno A, Cacho I, Canals M, Prins MA, Sánchez-Goñi MF, Grimalt JO, Weltje GJ (2002) Saharan dust transport and highlatitude glacial climatic variability: the Alboran sea record. Quat Res 58:318-328

21. Nelson PE, Toussoun TA, Marasas WFO (1983) Fusarium species. A manual for identification. Pennsylvania State University Press, University Park, PA

22. Ooka JJ, Kommedahl T (1977) Wind and rain dispersal of Fusarium moniliforme in corn fields. Phytopathology 67: 1023-1026

23. Palmero D, de Cara M, Iglesias C, Tello JC (2008) Fusarium species isolated from water from fluvial channels and sea beds of the south eastern coast of Spain. J Plant Pathol 90(3):48-49

24. Palmero D, Iglesias C, de Cara M, Lomas T, Santos M, Tello JC (2009) Species of Fusarium Isolated from River and Sea Water of Southeastern Spain and Pathogenicity on four plant species. Plant Dis 93(4):377-385

25. Prospero JM, Blades E, Mathison G, Naidu R (2005) Interhemispheric transport of viable fungi and bacteria from Africa to the Caribbean with soil dust. Aerobiologia 21:1-19

26. Prospero JM, Lamb PJ (2003) African droughts and dust transport to the Caribbean: climatic change implications. Science 302 : 1024-1027

27. Schmale DG, Leslie JF, Zeller KA, Saleh AA, Shields EJ, Bergstrom GC (2006) Genetic structure of atmospheric populations of Giberella zeae. Phytopathology 96:1021-1026

28. Schumann GL, D'Arcy CJ (2006) Essential plant pathology. American Phytopathological Society, St. Paul 
29. Smither-Kopperl ML, Charudattan R, Berger RD (1998) Dispersal of spores of Fusarium culmorum in aquatic systems. Phytopathology 88:382-388

30. Tello JC, Lacasa A (1990) Fusarium oxysporum en los cultivos intensivos del litoral mediterráneo de España. Fases parasitaria (Fusariosis vasculares del tomate y del clavel) y no parasitaria. Bol San Veg Plagas 19:1-190
31. Tello JC, Vares F, Lacasa A (1991) Análisis de muestras. In: Manual de laboratorio: Diagnostico de hongos, bacterias y nematodos fitopatógenos. Ministerio de Agricultura Pesca y Alimentación. Madrid, pp 39-48

32. Wu PC, Tsai JC, Li FC, Lung SC, Su HJ (2004) Increased levels of ambient fungal spores in Taiwan are associated with dust events from China. Atmos Environ 38:4879-4886 